\title{
Gymnaster iblandt skytter \\ - en analyse af gymnastikkens vilkår i Odense Amts Skytteforening 1866-1929
}

\author{
Af Johnny Wøllekær
}

I forrige århundrede konstituerede den moderne gymnastik, der udsprang fra de filantropinske pædagogik- og kulturstrømninger i Mellemeuropa, sig som en kropskulturel faktor i Danmark. Essentiel for gymnastikkens udbredelse var etableringen af en række gymnastikmiljøer. Ved 1814-skoleloven blev faget gymnastik integreret i almueskolen, og fra midten af århundredet tog ligeledes højskolerne, private gynmastikinstitutter, frie gymnastikforeninger og skytteforeningerne gymnastik på programmet ${ }^{1}$.

Skytteforeningernes ideologiske målsætning var overvejende af nationalpatriotisk karakter. Afgørende indflydelse havde nederlaget til Preussen i 1864 og de efterfølgende nationalromantiske strømninger, der gav gødning til den fremblomstrende skyttebevægelse. Drivkraften var revanchetanken og visionen om Sønderjyllands tilbageerobring. Hensigten med skytteforeningerne var at forbedre de kommende værnepligtiges forsvarskraft og give dem skydefærdigheder før selve militærtjenesten. Skytteforeningerne skulle virke som en forskole for de værnepligtige, samt give forhenværende soldater lejlighed til at vedligeholde deres færdigheder. Midlet var fortrinsvis skydeøvelser, der muligvis blev kombineret med eksercits. Gymnastik var oprindeligt ikke på skytteforeningernes repertoire, den blev dog snart integreret, eftersom den sikrede foreningernes sammen- hold i vinterhalvåret, hvor skydeøvelserne måtte indstilles.

Men også ideologisk blev gymnastikken integreret i skytteforeningerne. Gennem gymnastikkens rationelle prægning af skytternes legeme ville deres sundhedstilstand forbedres, hvilket ville være gavnligt ved militærindkaldelsen. Kaptajn Klüver, der på dette tidspunkt var bestyrelsesmedlem i Odense Amts Skytteforening, publicerede i 1869 en lille pjece, hvor der bl.a. kan læses om legemsøvelsernes rolle:

»... vi anse den (legemsøvelser) for sideordnet med Skarpskydning... Hæren trænger ligesaameget til, at dens Rekrutter ved Indkaldelsen have et vel udviklet Legeme. Vi skulle her aldeles lade ude af Betragtning de store Fordele, den unge Mand i det Hele har af Legems $\emptyset$ velser $\ll^{2}$

I årtierne frem mod århundredskiftet steg gymnastikkens popularitet kraftigt. I 1888 dyrkede 5.444 personer gymnastik i skytteforeningernes regi, i 1892 var det 6.211, og i 1898 var antallet vokset til 10.092. Altså næsten en fordobling på blot 10 år. Gymnastikkens popularitet var imidlertid ikke ligeligt fordelt mellem de forskellige landsdele og deres respektive amtsskytteforeninger. Flest gymnaster havde h.h.v. Odense og Svendborg Amts Skytteforeninger, der tilsammen tegnede sig for henved $1 / 3$, dernæst fulgte Ribe og Holbæk amter med omtrent $1 / 6$. Halvdelen af gårdmandsgym- 
nasterne fandtes altså i disse 4 amtsskytteforeninger, medens den anden halvdel fordelte sig på de resterende 25 amtsskytteforeninger ${ }^{3}$. Hvorfor denne ulige fordeling? Det må antages, at de potentielle eksistensvilkår gymnastikken blev budt i de lokale amtsforeninger også afspejlede den popularitet og udbredelse gymnastikken nød. Skal der etableres en bredere forklaringsramme for de mange gymnaster i de fynske amtsskytteforeninger skal svaret formentlig søges i eksistensvilkårene. Principielt må gymnastikkens eksistensvilkår kunne defineres ud fra tre parametre:

1. ledelsens interesse for gymnastik,

2. gymnastikkens fysiske rammer, og

3. instruktørernes uddannelsesniveau.

\section{Odense Amts Skytteforening}

Efterhånden som antallet af skytteforeninger inden for amterne voksede, sluttede foreningerne sig sammen i amtsskytteforeninger. De første amtsforeninger blev etableret på Fyn, hvor Svendborg Amts Skytteforening blev stiftet 1865 af Kaptajn Edvard Nielsen ${ }^{4}$. Den 3. januar det efterfølgende år indkaldte en række embedsmænd og officerer til stiftende generalforsamling for Odense Amts Skytteforening på Odense rådhus. I mødet deltog ialt 170 personer, deriblandt stiftamtmand Unsgaard, der valgtes til formand. Efter konstituering af vedtægterne, der var identiske med vedtægterne for Svendborg Amts Skytteforening, inddeltes foreningen i 19 skyttekredse. Medlemstallet var endnu relativt beskedent. I marts måned blev det opgjort til 3.853 personer, hvoraf 1.354 var yngre skytter, 164 ældre skytter, men det største kontingent tegnede de bidragydende medlemmer sig for med 2.334 personer. I løbet af 1860 'erne og 70 'erne faldt medlemstallet for igen at stige i 1880 'erne. Efter at medlemstallet i en årrække havde stabiliseret sig omkring 4.000 personer, oplevede amtsforeningen under 1 . Verdenskrig igen en mindre medlemskrise, der i årsberetning 1915 blev kommenteret således:

»Den temmelige store Tilbagegang i Medlemsantallet for i Aar - særlig blandt Skytter og mandlige Gymnaster - skyldes de for Tiden vanskelige Forhold, idet en stor Del af Medlemmerne har været indkaldt til Sikringsstyrken, hvorved Kredsene mange Steder har været berøvet den ledende Kraft ved Indkaldelse af deres Kredsformand eller Delingsførere. For Skydningens Vedkommende kommer der Vanskelighederne ved at skaffe Ammunition $\ll^{5}$

Da verdenskrigen ikke længere kastede skygger over Europa kunne Odense Amts Skytteforening igen for $\varnothing \mathrm{ge}$ sin medlemsskare betragteligt til over 6.000 personer i år 1929. En vækst der ikke mindst skyldtes en forvandling i medlemskonstellationen. Fra år 1897 figurerer der i årsberetningerne medlemmer, der udelukkende praktiserede gymnastik, og på generalforsamlingen året efter vedtoges det, at personer som indbetalte $50 \varnothing$ re årligt, kunne deltage i kredsenes gymnastikøvelser ${ }^{6}$. Medlemsfremgangen var fortrinsvis en konsekvens af tilgangen af »rene« gymnaster, mens skytterne kontinuerligt var på retræten, og fra 1920 'erne var gymnasterne altdominerende! Gymnasternes dominans afspejledes ligeledes af, at der fra 1901 optræder skyttekredse, der udelukkende $\emptyset$ vede gymnastik. I 1901 var det en enkelt kreds, ti år senere var det 4 kredse, i 1920 var det 7 og ved sprængningen af De Danske Skytte og Gymnastikforeninger i år 1929 var det hele 49 ud af ialt 69 skyttekredse, der udelukkende havde gymnastik på repertoiret.

En anden væsentlig faktor for gymnastikkens fremgang var de kvindelige gymnasters entré på arenaen. Historien om kvindegymnastikken blev ligesom $i$ andre amts- 
skytteforeninger ${ }^{7}$ en succeshistorie, og kvinderne fik stigende dominans i skyttekredsene efter århundredskiftet. I år 1906 besluttede Overbestyrelsen officielt, at foreningerne kunne optage lokale kvinder i medlemskaren ${ }^{8}$. I adskillige af skyttekredsene under Odense Amts Skytteforening var pigegymnastikken imidlertid påbegyndt tidligere. I Revninge skyttekreds nævnes pigegymnastik allerede i 1888 , og i en medlemsoversigt fra 1900-årsberetningen opregnes 50 pigegymnaster. I år 1907 optræder kvindelige gymnaster på den officielle medlemsoversigt, og konsekvensen af Overbestyrelsens bestemmelse kan følges de næste årtier, hvor kvindegymnasterne fik stadig større tyngde i medlemsstatistikken. Fra midten af 1920'erne var der status quo på vægtskålene over mandlige og kvindelige gymnaster. Mens den fremstormende gymnastik havde velsignede dage i 1920'erne, var situationen for skytterne, der havde konstant medlemstilbagegang, stadig mere kritisk. Gymnasternes altdominerende position afspejledes - akkurat som i landsorganisationen - i flere brydningstendenser. Selvom amtsforeningen i 1920 omdøbtes til Odense Amts Skytte- og Gymnastikforening, kunne det ikke udviske uoverensstemmelserne. Gymnasterne krævede udvidet repræsentation i bestyrelsen og større indflydelse på foreningen. På generalforsamling 1926 stilledes forslag om sprængning af foreningen i h.h.v. en skytte og en gymnastikforening, men forslaget blev forkastet på en bestemmelse om $3 / 5$-flertal ${ }^{9}$. Blot 3 år efter, $\mathrm{i}$ året for landsorganisationens sprængning, aktualiseredes spørgsmålet igen, og blev denne gang vedtaget med $»$ stort Flertal $\ll^{10}$.

\section{Gymnastikkens фvelser}

I konstitutionsperioden koncentrede amtsskytteforeningen sine hovedkræfter på skydning og exercitsøvelser, »men snart kom Exercitsen i Miskredit og Foreningen slog indpaa en ganske anden nyttig og gavnlig Virksomhed, i det man tog Gymnastik, Vaaben og Legemsøvelser til i Forening med Skydeøvelser at udgjøre Foreningens egentlig Hovedformaal ${ }^{11}$. Om idégrundlaget for legems $\varnothing$ velserne skrev bestyrelsesmedlem kaptajn Klüver i 1869:

»... kom det an paa at finde saadanne Øvelser, som more saameget, at Morskaben overvejer Anstrengelsen, paa samme Tid som Øvelserne virkeligt uddanne de unge Mænds Legemer netop i de Retninger, hvori det kan komme dem selv tilgode under Tjenesten i Hære $\ll^{12}$

Betonede $\varnothing v e l s e r n e ~ i k k e$ forn $\varnothing j$ jelsesmomentet, ville de næppe appellere til de unge landmandssønner, der $\gg$ i det daglige Liv slide saameget paa sin fysiske Kraft, at han ikke kan forstaa, at det kan være rigtigt ogsaa om Søndagene at bruge dem $\ll^{13}$. For at favorisere gymnastikken og fornøjelsesmomentet optimalt udarbejdede bestyrelsen for Odense Amts Skytteforening i 1868 et legemsøvelsesprogram. Programmet, der ligeledes fandt anvendelse i Svendborg og Vejle amtsskytteforeninger, var et sammensurium af hurtigløb, løb, højde- og længdespring med og uden gevær samt boldspil. Året efter fulgte Overstyrelsen initiativet op og publicerede »Haandbog i Gymnastik for Delingsformænd ved Amts-Skytteforeningerne « ved V. la Cour, hvis øvelsesvalg var næsten identisk med Odense Amts Skytteforenings program. Øvelserne, der var inspireret af Gutsmuths, var velkendte fra hæren og skolevæsenet.

Et situationsbillede af legemsøvelsernes status og udbredelse findes $i$ årsberetningen 1883, der oplyser, at gymnastikken har »fundet megen Tilslutning i den forløbne Vinter «. Den gymnastik der praktiseredes var »Springning, Voltigering, Vaabenøvel- 
ser, sidstnævnte dog kun i ringe Grad, men især synes de faa vigtige og nyttige Trapez og Smidigheds $\emptyset$ velser at have vundet stærk -indgang og de ere paa flere Steder drevne meget vidt $\ll^{14}$. Amtsskytteforeningen $\emptyset n$ skede ligeledes barreøvelser introduceret, »men da faa Midler, hvormed det virker, have endnu ikke tilladt Anskaffelsen af saa kostbare Apparater ${ }^{15}$.

I skyttebevægelsens etableringsfase blev gymnastikbegrebet ikke defineret så snævert $^{16}$, som det senere blev tilfældet, og i Odense Amts Skytteforening inkluderede begrebet også boldspil:

»Endeligt bestræbe vi os paa at indføre Kricket-Spillet i hele Foreningen, og Sagen har god Fremgang, idetmindste 16 Delinger $\varnothing v e$ i større eller mindre Grad spillet.«17

Når Amtsskytteforeningen i 1860'erne agiterede for introduceringen af kricketspillet $i$ skyttekredsene var det fordi det »...paa eengang Øve Øje, Arm og Been... $\ll^{18}$

Men den militærinspirerede gymnastik alá tysk turn (redskabsøvelser) kombineret med Gutsmuths tyske gymnastik og Nachtegalls voltigering og smidigheds $\varnothing$ velser var stadigvæk den dominerende gymnastikaktivitet. Mod århundredets slutning påbegyndte flere danske skytteforeninger at dyrke den svenskinspirerede lingske gymnastik. I provisorieårene blev Linggymnastikken i flere skyttekredse brugt som en protest mod officerstandens militærgymnastik. Mens den svenskinspirerede gårdmandsgymnastik nød stor popularitet i den politisk engagerede Svendborg Amts Skytteforening, blev den ikke eksponent for samme politiske manifestation i Odense Amts Skytteforening. Frekventeres det jubilæumsskrift som Klaus Berntsen, der foruden bestyrelsesformand også var folke- tingsmand for venstre, skrev i 1891, demonstreres dette tydeligt:

»Den latterlige Anskuelse at svensk Gymnastik særlig var Venstregymnastik og dansk Gymnastik noget som Højremænd særlig skulde lægge Vægten paa, har heldigvis aldrig haft Tilhængere i Odense Amts Skytteforening, hverken i dens Forretningsudvalg eller blandt dens Medlemmer. ${ }^{19}$

Allerede $\mathrm{i}$ år 1888 havde amtskytteforeningen imidlertid demonstreret interesse for den lingske gymnastik, eftersom »svenske Studenter, paa Forretningsudvalgets Foranstaltning afholdte Præsentation i svensk Gymnastik « ${ }^{20}$, og samme år praktiserede Sdr. Nærå svenskinspireret gymnastik. Det efterfølgende år $\emptyset$ vede yderligere 3 skyttekredse Linggymnastik, samtidig med at amtsskytteforeningen kunne sende de første medlemmer på instruktørkursus i »svensk« gymnastik. Omkring 1890 praktiserede henved hver tredie gymnastikkreds den lingske gymnastik, men først efter århundredskiftet blev den svenskinspirerede $\varnothing$ velsesform dominerende.

\section{Gymnastikkens rum}

Under skyttebevægelsens etableringsfase blev gymnastikken hyppigt praktiseret under improviserede og primitive vilkår. Enten på bygaden, en vilkårlig græsmark eller i ladebygningen hos en velvillig gårdmand. I årsberetningen 1918 blev Hans Chr. Hansen, Vigerslev, takket for sin trofasthed for skyttesagen, og her hedder det bl.a.:

»Meget er forandret indenfor Skytteforeningerne i den lange Aarrække, vor gamle Skytte har været Medlem; men naar vi hører ham fortælle, hvorledes de af Mangel paa Lokaler maatte holde Gymnastik paa Farstrup Gade..... $\ll^{21}$

I Åsum skyttekreds var gymnastikfaciliteterne tilsvarende uprætentiøse, idet som- 


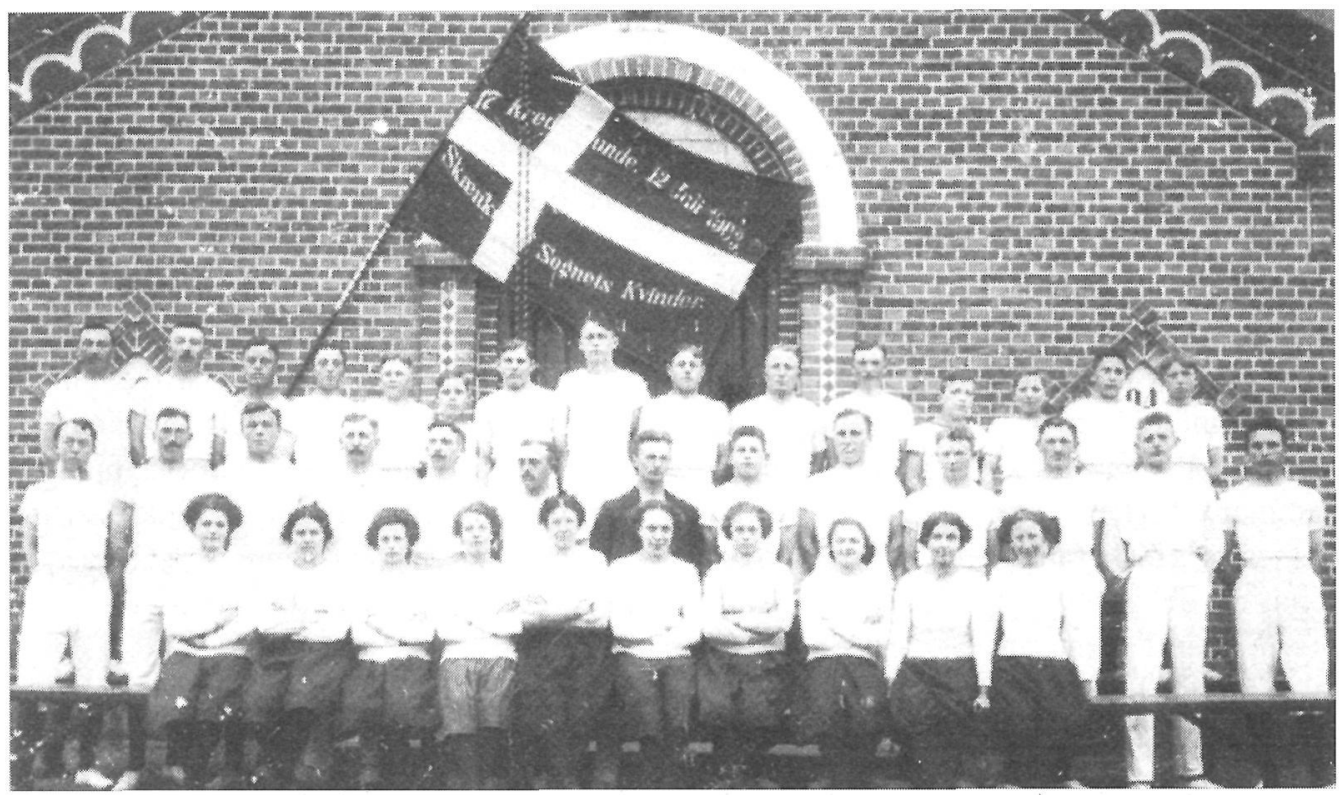

Gymnaster foran Lunde Forsamlingshus i 1914. Som det fremgår af fanen, udgjorde Lunde 17. Kreds, og som i de fleste kredse var fanen skanket af sognets kvinder. (Otterup Lokalarkiv).

mergymnastikken endnu i 1890'erne foregik på en bræddebresje, der var udlagt $\mathrm{i}$ Raagelund skov. Om gymnastikken på den interimistiske gulvbelægning skrev en københavner i »Dansk Skytte Tidende« årg. 1891:

»... Denne Løvsal og Højsal var det, jeg kom ind i forleden Aften efter Solnedgang. Og De kan ikke tænke Dem, hvor morsomt her at se over 20 hvidklædte unge Bønderkarle udføre ordnede gymnastiske Idrætter med Kraft og Ynde i den grønne skov, hvor Aftenens Fred raadede rundt omkring $\ll^{22}$.

Manglen på velegnede $\emptyset$ velseslokaler og faciliteter var i begyndelsesfasen et fundamentalt problem for mange af skyttekredsene. Gymnastikken var oprindeligt en vinteraktivitet, hvor skydningen måtte indstilles. Den konsoliderede skytteforeningernes sammenhold og fællesskab i den kolde årstid, men kravet var selvsagt indendørsfaci- liteter. Hovedparten af skyttekredsene var landkredse uden skolegymnastiksale, hvorfor skyttekredsene måtte tage sagen i egen hånd og oprette såkaldte $\emptyset v e l s e s h u s e$ eller forsamlingshuse. Den fundamentale indflydelse $\emptyset$ velseshusene og forsamlingshusene fik for gymnastikkens ekspansion i Odense Amt demonstreres af 1891-jubilæumsskriftet:

»Et vigtigt Middel til fremme af Gymnastiken og Legemsøvelser paa Landet er de mange $\emptyset$ velses- og Forsamlingshuse, der findes omkring i Vort Land, og af hvilke der nu findes henved 50 i Odense Amt, næsten allesammen rejst ved Bidrag af Amtsskytteforeningen og de stedlige Skyttekredse $\ll^{23}$.

Sideløbende med de praktiske hensyn, fik $\emptyset$ velseshusene ligeledes en psykologisk betydning for udbredelsen af gymnastikken. Indendørsrummet eliminerede opmærksomheden fra hverdagens konventioner og 
markerede for karlegymnasterne en distance til udendørsarbejdet på markerne. Øvelseshusene markerede grænsen mellem arbejde og fritid - eller en monumental barriere mellem natur og kultur ${ }^{24}$.

Med $\emptyset$ velses- og forsamlingshusene etableredes en organisatorisk og social interaktionsramme for skyttekredsene. Bygningerne var ikke alene omdrejningspunktet for vintergymnastikken, de var ligeledes stedet for den årlige generalforsamling, sammenkomster, fester og lignende arrangementer. Her arrangeredes hen på senvinteren de obligatoriske gymnastikopvisninger. Forsamlingshusene var mere end blot en vilkårlig bygning. De var et samlingspunkt, der på interiøret bar skyttekredsens fingeraftryk. Det var her skyttekredsene opbevarede bevægelsens symboler som ribbevægge, plinte, bomme, træheste og de stolte dannebrogsfaner, som »konerne « havde skænket foreningen, og hvorpå de havde broderet manende indskrifter, som f.eks. $»$ Vi bytter ej Banner, vi skifter ej Skjold $\ll^{25}$

Med forsamlingshusene skabtes også en autonomisering af skytteforenings- og navnlig gynmastikkulturen. De var såvel en psykologisk som en fysisk manifestation, der profilerede skyttebevægelsen i forhold til det omgivende landsbymilj $\varnothing$ - med andre ord et væsentligt element $i$ foreningernes selvforståelse og identitet. I forsamlingshusene fandt den selvbevidste bondestand de ideelle rammer for videreførelsen og iscenesættelsen af kollektivoplevelser, som fællessang og de rituelle indmarcher, de var blevet præsenteret for, og havde lært at elske, på de grundtvigianske folkehøjskoler.

På landsplan blev forsamlingshustanken konstitueret i midten af 1880 ' $\mathrm{erne}^{26}$. I perioden 1885-1905 opførtes alene 900 forsamlingshuse i Danmark. I år 1880 var det kun $1,7 \%$ af de danske sogne, der havde et for- samlingshus. Ved århundredskiftet var tallet steget til 36\%, og i 1919, hvor forsamlingshusbyggeriet var stagnerende, var det $60,3 \%$ af landets sogne, der var i besiddelse af et forsamlingshus ${ }^{27}$. De mange oprettelser af forsamlingshuse afspejlede sig ligeledes i Overbestyrelsens Årsberetninger. Før 188586 klages konstant over mangel på lokalefaciliteter og gymnastikkens dårlige vilkår, men herefter meldes om stadig fremgang ${ }^{28}$.

Den tiltagende interesse for gymnastik afspejles direkte i væksten af de særlige $\emptyset$ velseshuse, hvis primære formål var at fungere som gymnastiklokale.

1888: 127 øvelseshuse

1890: $262 \varnothing$ velseshuse

1895: $313 \varnothing$ velseshuse

1900: $435 \varnothing$ velseshuse

1905: $678 \varnothing$ velseshuse

1910: $732 \varnothing$ velseshuse $^{29}$

Byggeriet af forsamlingshuse og $\varnothing$ velseshuse modsvarede dog langtfra behovet, og $\mathrm{i}$ 1911 måtte L.F.C. Krogh konstatere, at $\gg \mathrm{Li}$ gesom tidligere $\varnothing$ ves i enkelte Kredse endnu Gymnastik i ret primitive Lokaler $\ll^{30}$.

Blandt de fremmeligste områder for forsamlingshusoprettelser var de tre fynske amtsråd - Svendborg, Assens og Odense amtsråd. Hvor landsgennemsnittet af sogne med forsamlingshus i 1919 var 60,3\%, var procenterne på Fyn betragtelig højere. Lavest var Assens amtsråd med 62,5\%, dernæst Odense med 68,8\%, og højest var Svendborg amtsråd med hele $71,2 \%^{31}$. Geografisk var de fynske forsamlingshuse fortrinsvis placeret på det grundtvigianske Østfyn - fra egnen vest for Svendborg i et bælte op mod Kerteminde.

Landets første $\emptyset$ velseshus var ligeledes fynsk, nemlig i den midtfynske landsby, Ryslinge - under Svendborg amt - i 1871. 
Allerede året efter fik Odense amt, og dermed Odense Amts Skytteforening, sit første $\emptyset$ velseshus, idet der i Ferritslev (5. kreds omfattende Rønninge, Rolfsted og Birkende) byggedes en tro kopi af det i Ryslinge ${ }^{32}$. Den store »forsamlingshusperiode « kom først i midten af 1880 'erne og frem til århundredskiftet. Af de $123 \emptyset$ velses- og forsamlingshuse der opførtes mellem 1872 og 1934, blev alene de 102 bygget mellem 1885 og 1909. En blomstringsperiode der falder samtidig med medlemsfremgangen.

Opførelsen af et forsamlingshus var dog langtfra automatisk knyttet sammen med en skytte og gymnastikforening, eftersom husene ligesåvel var hjemsted og kulturelt omdrejningspunkt for andre af den grundtvigianske gårdmandskulturs aktiviteter og traditioner f.eks. foredragforeninger, sangforeninger, forsikringskasser, dilletantteater, fester etc. Forsamlingshusenes mangfoldighed i aktiviteter ses af de næsten identiske formålsparagraffer. Her er det paragraffen for Ejlby forsamlingshus (1896) på Nordfyn:

»Selskabets Øjemed er Erhvervelsen af Bygningen $»$ Ejlby Forsamlingshus « til deri ved Forhandlingsm $\varnothing-$ der, Foredrag og Sang at udbrede folkelig Oplysning. Huset er endvidere bestemt til Afbenyttelse for voxne og Børn til Uddannelse i Gymnastik....« ${ }^{33}$

Ligeledes kunne forsamlingshusene være for små til gymnastik. I Åsum sogn indviedes et forsamlingshus i 1879 , bygningen var dog med sine 10 gange 15 alen gulvplads for lille til gymnastikøvelser, og skyttekredsen fortsatte med friluftsgymnastik ${ }^{34}$.

Om »gymnastikkens rum « oplyser 1892 årsberetningen, at der til rådighed for de 42 gymnastikkredse var 32 øvelseshuse, 4 gymnastiksale og 4 lader, mens 2 kredse måtte praktisere gymnastiktræning under åben himmel. Ved århundredskiftet var faciliteterne blevet væsentligt forbedret. Der var stadig 42 kredse som dyrkede gymnastik, og de disponerede over $38 \varnothing$ velseshuse og 5 gymnastiksale - en skyttekreds havde p.g.a. $\sin$ størrelse rådighed over $2 \varnothing v e l s e s h u s e$. Ingen måtte længere praktisere friluftsgymnastik. Problemerne med kvalificerede lokalefaciliteter synes elimineret med indgangen til det 20. århundrede! Men forsamlingshusene var ingen statisk masse, snarere tværtimod. Konsulteres årsberetningen 1928 hedder det om 1 . hovedkreds, at

»Adskillige af Hovedkredsens Forsamlingshuse eller $\emptyset$ velseshuse er i de sidste Par Aar blevne udvidede eller ombyggede. - Det er glædeligt at se den stigende Interesse, der findes - saavel hos yngre som ældre for gennem lyse og rene Forsamlingshuse at skabe en smuk Ramme om det Ungdomsarbejde, som har sit Tilhold indenfor disse; og det er glædeligt at kunne sige, at overalt i Hovedkredsen staar Gode og velindrettede Huse til Brug for Ungdommen, blot den vil benytte dem $\ll^{35}$.

Brugerne af forsamlingshusene var en meget heterogen gruppe, hvilket ligeledes gælder initiativgruppen. Det kunne være den lokale skyttekreds og/eller andre af landbefolkningens »græsrodsbevægelser«. I lighed med tidens andre innovationer opførtes forsamlingshusene som et andelsforetagende, hvor sognebeboerne tegnede aktieposter efter evne og interesse for sagen. Normalt kunne brugerne af forsamlingshuset $\gg$ benytte Huset, imod at betale for Lys, Varme og Rengøring. Naar disse Foreninger derimod agter at afholde festlige Sammenkomster, offentlige Foredrag eller lignende, maa der betales for Brugen af Huset « ${ }^{36}$. I 1906 betalte Barløse gymnastikforening $10 \mathrm{kr}$. årligt for belysningen $\mathrm{i}$ vintermånederne.

\section{Delingsfфrerne}

Uden veluddannede og kvalificerede instruktører - delingsførere - der kunne fylde forsamlingshusene med de kommandoråb 
som dikterede takten for gymnastgeleddernes skiftende stillinger, kunne skyttekredsene imidlertid ikke lukrere på de tilrådighedværende faciliteter. Uden delingsførerne, der såvel praktisk som teoretisk var bannerførere for skyttebevægelsens aktiviteter, ingen gymnastik!

De første gymnastikdelingsførere i skyttebevægelsen rekrutteredes fortrinsvis fra militæret, hvor instruktørgerningen i skydning og gymnastik var et æreshverv for hjemsendte korporaler og underofficerer. I de skyttekredse, der lå nær en garnisonsby, var det normalt, at officererne med mellemrum forestod aktiviteterne. Med disse kontakter var skyttebevægelsens tilknytning til militæret garanteret ${ }^{37}$.

Det første initiativ til en reel gymnastikuddannelse indenfor skyttebevægelsen tog Overbestyrelsen i 1871, men da initiativet led skibbrud, pustede de lokale amtsskytteforeninger selv livgivende ild i processen. Siden 1816 havde Hærens Gymnastikskole haft monopol på gymnastiklæreruddannelsen, men fra 1878 opblødtes denne struktur langsomt. Flere grundtvigianske folkeh $\varnothing \mathbf{j}-$ skoler, som Vallekilde og Askov, begyndte selv at afholde kurser for delingsførere. På 14 og 20 dages højskolekurser kunne skyttekredsene få nyuddannet kvalificerede delingsførere.

I Odense Amts Skytteforening tog bestyrelsen initiativ til oprettelsen af et delingsførerkursus på Særslev folkehøjskole, hvor den nyvalgte formand Klaus Berntsen var forstander. Om kurserne fortæller Klaus Berntsen i 1916: »For at fremme Gymnastikken, blev der i en Række paa Særslev Højskole indrettet Kursus for Uddannelse af Delingsførere under Ledelse af Gymnastiklærerne Jørgensen og Nielsen af 5 . Bataillon. Deltagerne fik tillige adgang til at høre nogle Foredrag paa Højskolen i de Uger, dette Kursus varede. Det første Kur- sus afholdtes 1895 og var besøgt af 19 Deltagere. $\ll^{38}$

Sideløbende med kurserne på Særslev højskole sendte Odense Amts Skytteforening ligeledes gymnaster til delingsførerkurser på såvel Askov som Vallekilde højskoler senere også Ryslinge og Hadsten højskoler.

Gennemgående er Odense Amts Skytteforenings årsberetninger tavse med hensyn til delingsførerne og deres uddannelsesmæssige baggrund, men for perioden 1892 1909 eksisterer nogle informationer, der demonstrerer processen væk fra militæruddannede lærere over til skyttebevægelsens egne gymnastikfolk. I 1892 var lærer-antallet $\mathrm{i}$ de 42 gymnasticerende skyttekredse ialt 47, heraf var 26 uddannet ved befalingsmandsskoler i militæret, 7 under Overbestyrelsen, og 14 var uddannet »ad anden vej $\aleph^{39}$. Blot nogle år senere ved århundredskiftet var situationen skiftet, eftersom 22 delingsførere var udsprunget fra kurser under Overbestyrelsen, 19 fra militæret og 8 ad anden vej ${ }^{40}$. I 1909 var tendensen fuldbyrdet med 38 Overstyrelsesuddannede og kun 5 fra militæret samt 11 ad anden vej. I takt med gymnastikkens voksende popularitet mistede militæret sit greb om skyttebevægelsesgymnastikken.

Efter kvindegymnastikkens entré på skyttesagsarenaen i begyndelsen af det 20 . århundrede, opstod en naturligt efterspørgsel på kvindelige gymnastikinstruktører, og i 1909 besluttede Odense Amts Skytteforening at give $\varnothing$ konomiske subsidier til kvinders deltagelse i delingsførerkurser. En støtteordning der blev brugt, og i 1922 konstaterede formanden $\mathrm{i}$ årsberetningen, at »Ifølge indberetningerne fra Kredsene findes der i Foreningen 89 uddannede Gymnastikledere, nemlig 64 mandlige og 25 kvindelige. $\ll^{41}$

Tilsyneladende havde Odense Amts 
Skytteforening held til at regulere antallet af nyuddannede delingsførere efter behovet i skyttekredsene - i hvert fald hvis de manglende beklagelser $i$ årsberetningerne må tages som udtryk for dette. Sammenlignet med mængden af delingsførere på landsplan var Odense Amts Skytteforening førende i en opgørelsen fra Overbestyrelsen i 1901 - kun overgået af naboamtsskytteforeningen fra Svendborg amt $\mathrm{t}^{42}$.

Til at garantere kvaliteten af gymnastikken og som inspiration for delingsførerne engagerede Odense Amts Skytteforening i år 1894 og fremefter gymnastikinspektører, hvis opgave det var, at foretage »Inspektionsrejser til de gymnasticerende Kredse for paa instruktiv Maade at give Anvisning, Forskrift og Vejledning baade til Lærere og Elever.«43

\section{Gymnastik og grundtvigianismen}

Beretningen om Odense Amts Skytteforening 1866-1929 er generelt en traditionel amtsskytteforeningshistorie ${ }^{44}$, men det er bemærkelsesværdigt, hvorledes der fra foreningens etableringsfase kan efterspores en kolossal gymnastikfiksering - et velment engagement der realiseredes via oppriotering af gymnastikaktiviteter. Egenhændigt var Odense Amts Skytteforening initiativtager til en gymnastikhåndbog, der skulle udbrede kendskabet til legemsøvelser, boldspil m.v. Amtsskytteforeningen agite- rede ihærdigt for oprettelsen af forsamlingshuse og øvelseshuse, ligesom foreningen finanserede uddannelsen af delingsførere. Gymnastikken lå Odense Amts Skytteforenings bestyrelse på hjertet, og indsatsen bar frugt på skyttekredseniveau! Odense Amts Skytteforening havde sammenlignet med lignende amtsskytteforeninger betragtelig flere forsamlingshuse og delingsførere end gennemsnittet. Gymnastikkens popularitet $\mathrm{i}$ amtet skyldtes derfor ikke mindst amtskytteforeningen, der engagerede sig i gymnastikken, og skaffede den bedre eksistensvilkår end i mange andre landsdele.

Forudsætningen for at den »gymnastikspire « som Odense Amts Skytteforening plantede i tiden omkring århundredskiftet kunne blomstre frem i det fynske gårdmandsmiljø, var en næringsrig kulturel grobund. På Fyn, hvor grundtvigianismen og de »folkelige « bevægelser stod centralt på grund af markante foregangsmænd som f.eks. Christen Kold og hans version af »skolen for livet «, havde de »grundtvigianske« initiativer a priori »attraktive« vækstbetingelser. Det var ingen tilfældighed, at landbefolkningen på Hindsholm, en rigtig friskoleegn, fra begyndelsen var skyttesagsbegejstrede. Historien om gymnastikkens popularitet i Odense Amts Skytteforening er således også historien om en landsdel, der hørte til en af grundtvigianismens og de »folkelige« bevægelsers højborge. 


\section{Noter}

1. Trangbæk, Else: »Mellem leg og disciplin«, Åbybro 1989, s. 49-66.

2. Klüver (kaptajn): »Om Skyttebevægelsen, dens Organisation, bevæbning og øvelser«, 1869, s. 20.

3. Ramsing, P.E.M.: »Gymnastiken i De Danske Skytteforeninger «, 1902, s. 18.

4. Korsgaard, Ove: »Krop og kultur«, Odense 1986, s. 43.

5. Aarsberetning for Odense Amts Skytteforening 1915.

6. Aarsberetning for Odense Amts Skytteforening 1916.

7. Bruhn, Verner: »Plint og talerstol«, Esbjerg 1979, s. 23.

8. Krogh, L.F.C.: »Skyttesagen i Danmark«, Kbh. 1911, s. 364.

9. Aarsberetning for Odense Amts Skytte- og Gymnastikforening 1926.

10. Aarsberetning for Odense Amts Skytte- og Gymnastikforening 1929.

11. Berntsen, Klaus: »Odense Amtsskytteforening gennem 25 Aar« Odense 1891, s. 29.

12. Klüver op cit. s. 21.

13. Ibid.

14. Aarsberetning for Odense Amts Skytteforening 1883.

15. Ibid.

16. Hansen, Jørn: »Sport og Dansk idræt« (I: Kropskultur og idræt. Idrætshistorisk årbog 1990, 6 årg.) s. $74 \mathrm{ff}$.

17. Klüver op cit. 22-23.

18. Ibid.

19. Berntsen op cit. s. 32.

20. Aarsberetning for Odense Amts Skytteforening 1886.

21. Aarsberetning for Odense Amts Skytte- og Gymnastikforening 1918.

22. Frederiksen, Svend: »Fynske forsamlingshuse (I: Fynske Årbøger 1976), s. 91.
23. Berntsen op cit. s. 32.

24. Med artiklen »Provisorium og identitet - om krop og landskab《 (I: Kropskultur og idræt. Idrætshistorisk årbog 1990, 6 årg.) har Niels Kayser Nielsen lanceret teorien om forsamlingshusenes psykologiske betydning.

25. Den patriotiske faneindskrift var opført fanen for Sdr. Nærå skytteforening.

26. Thestrup, Poul: »Nærbutik og næringslovsomgåelse« Odense 1988, s. 332

27. Ibid. s. 332-333.

28. Lange, Kr.: »Den lingske gymnastik i Danmark $1884-1909$ «1909, s. 64.

29. Krogh op cit. s. 358.

30. Ibid.

31. Thestrup op cit. s. 333.

32. Frederiksen op cit. s. $83 \mathrm{ff}$.

33. Foreningsarkiver i Landsarkivet for Fyn, VII a, 2.

34. Frederiksen op cit. s. 90.

35. Aarsberetning for Odense Amts Skytte- og Gymnastikforening 1928.

36. Foreningsarkiver i Landsarkivet for Fyn, VII a, 1 .

37. Engelbrecht, John: »Vil du tænde må du brænde« Kirke Hyllinge 1989, s. 31-34.

38. Aarsberetning for Odense Amts Skytteforening 1916.

39. Aarsberetning for Odense Amts Skytteforening 1892.

40. Aarsberetning for Odense Amts Skytteforening 1900.

41. Aarsberetning for Odense Amts Skytte- og Gymnastikforening 1922.

42. Bruhn op cit. s. 24.

43. Aarsberetning for Odense Amts Skytteforening 1916.

44. Sammenlign f.eks. med Ribe Amt, som er beskrevet af Verner Bruhn op cit. 


\section{Litteratur- og kildeliste}

Aarsberetning for Odense Amts Skytteforening 18831919.

Aarsberetning for Odense Amts Skytte- og Gymnastikforening 1920-29.

Berntsen, Klaus: »Odense Amtsskytteforening gennem 25 Aar« Odense 1891.

Bruhn, Verner: »Plint og talerstol«, Esbjerg 1979.

Christiansen, Preben: »De Danske Skytte-, Gymnastik- og Idrætsforeninger 1861-1971«, Kbh. 1971.

Engelbrecht, John: »Vil du tænde må du brænde« Kirke Hyllinge 1989.

Foreningsarkiver i Landsarkivet for Fyn.

»Forsamlingshuse på landet. En redegørelse afgivet af kulturministeriets forsamlingshusudvalg « Kbh. 1979.

Frederiksen, Svend: »Fynske forsamlingshuse« (I: Fynske Årbøger 1976)

Hansen, Jørn: »Sport og Dansk idræt « (I: Kropskultur og idræt. Idrætshistorisk årbog 1990, 6. årg.)
Jacoksen, Hans Henrik (red.): »Odense Amts Skytteforening 1866-1991«, Odense 1991.

Klüver (kaptajn): »Om Skyttebevægelsen, dens Organisation, bevæbning og øvelser «, Odense 1869.

Korsgaard, Ove: »Kampen om kroppen« Kbh. 1982.

Korsgaard, Ove: »Krop og kultur «, Odense 1986.

Lange, Kr.: »Den lingske gymnastik i Danmark 18841909 « 1909

Nielsen, Niels Kayser: »Provisorium og identitet - om krop og landskab « (In: Kropskultur og idræt. Idrætshistorisk år-bog 1990, 6 årg.)

Ramsing, P.E.M.: »Gymnastiken i De Danske Skytteforeninger «, 1902.

Sørensen, Otto V. \& Ejler Møller: »Odense Amts Skytteforening 1866-1966«, Odense 1966.

Thestrup, Poul: »Nærbutik og næringslovsomgåelse « Odense 1988.

Trangbæk, Else: »Mellem leg og disciplin«, Åbybro 1989. 
